\title{
The influence of thalamosinusotomy under different constant intraocular pressures on aqueous outflow facility in isolated porcine eyes
}

\author{
Influência da thalamosinusotomia sob diferentes \\ pressões intra-oculares constantes na facilidade de \\ drenagem do humor aquoso em olhos de porco
}

Rafael Vidal Mérula', Ivan O. Haefliger ${ }^{2}$, Sebastião Cronemberger, Nassim Calixto ${ }^{3}$

\section{Resumo}

Objetivo: Avaliar o efeito da thalamosinusotomia ab interno, que é um procedimento cirúrgico experimental similar a esclerotalamotomia ab interno, na drenagem do humor aquoso. Métodos: Olhos de porco enucleados foram perfundidos com solução fisiológica de Krebs-Ringer e azul de tripan, sob diferentes pressões constantes de perfusão, após o procedimento cirúrgico experimental. A facilidade de drenagem e os tecidos corados/não corados foram medidos. Resultados: A facilidade de drenagem e a área sob a curva (fluxo) aumentaram com o aumento do número de incisões da thalamosinusotomia ( 0 a 4$)$. Olhos submetidos a thalamosinusotomia apresentaram mais tecido corado (conjuntiva, superfície externa e interna da esclera) que olhos submetidos a cirurgia sham, com diferença estatisticamente significativa $(\mathrm{p}<0,05)$. Conclusões: Os resultados sugerem que a facilidade de drenagem aumenta com o aumento do número de thalamus, diferente vias de drenagem são estimuladas após a thalamosinusotomia, e a drenagem uveoscleral pode ser uma via importante após o procedimento cirúrgico experimental.

Descritores: Thalamosinusotomia; Esclerotalamotomia; Humor aquoso; Drenagem/ métodos; Suínos

\footnotetext{
${ }_{2}^{1}$ Pós-graduando da Faculdade de Medicina da Universidade Federal de Minas Gerais - UFMG - Belo Horizonte (MG), Brasil. ${ }^{2} \mathrm{Head}$ of Laboratory of Ocular Pharmacology and Physiology of University Eye Clinic/Basel - Switzerland;

${ }^{3}$ Professor Titular de Oftalmologia da Faculdade de Medicina da Universidade Federal de Minas Gerais - UFMG - Belo Horizonte (MG), Brasil.

Trabalho realizado no Laboratory of Ocular Pharmacology and Physiology of University Eye Clinic/Basel - Switzerland e Universidade Federal de Minas Gerais - UFMG - Belo Horizonte (MG), Brasil
} 


\section{INTRODUCTION}

$\mathbf{T}$ he aim of the new ab interno glaucoma surgical techniques is to increase aqueous humor outflow in the conventional pathway ${ }^{(1.5)}$. It is assumed that the bulk of aqueous humor outflow resistance is generated in or near the inner wall endothelium of Schlemm's canal (SC) and/or in justacanalicular trabecular meshwork $(\mathrm{JCT})^{(6.8)}$. In consequence, these procedures intend to create a direct channel between the anterior chamber and SC.

Recently, a new ab interno surgical technique, called sclerothalamotomy (STT) ab interno, was proposed to reduce intraocular pressure (IOP) in glaucoma ${ }^{(5)}$. In this approach, a high-frequency diathermic probe is penetrated four times into the sclera through the trabecular meshwork and the Schlemm canal, forming a deep sclerotomy (i.e. "thalami") of $0.3 \mathrm{~mm}$ height and $0.6 \mathrm{~mm}$ width $^{(5)}$. The control of IOP after 24 months of follow up was satisfactory, and a low rate of complications was found ${ }^{(5)}$.

The exact participation of the uveoscleral pathway on the aqueous humor drainage is not definitively established in humans ${ }^{(0.10)}$. Most of the available reports comment on the unconventional pathway using animal models or mathematics formu$\mathrm{las}^{(0 \cdot 16)}$. And very low attention is given to the functioning of this via after glaucoma surgeries.

The purpose of this study is to explore the effect of the thalamosinusotomy (TST) ab interno, which is an experimental surgical procedure similar to STT ab interno, on aqueous humor drainage. Particularly, we want to address if this procedure increases the uveoscleral outflow, and what happens with the outflow facility under different constant pressures after this technique, using an in vitro model with porcine eyes.

\section{Methods}

\section{Sinusothalmotomie procedures (thalamosinusotomy)}

In adherence with the tenants of the ARVO Statement for the Use of Animals in Ophthalmic and Vision Research porcine eyes were obtained from a local abattoir immediately after the animal's death and were transported to the laboratory in ice-cold KrebsRinger's physiologic solution. Within 3 hours after death, the anterior chamber was cannulated by inserting a 27 gauge $(0.4 \mathrm{~mm})$ needle (Terumo Medical Corporation, Tokyo, Japan) through a $2 \mathrm{~mm}$ corneo-scleral tunnel.

Under a microscope (Wild M3B, Heergrugg,
Switzerland), a 20 gauge $(1.4 \mathrm{~mm})$ vitrectomy knife (Sharpoint ${ }^{\oplus}$, Surgical Specialties Corporation, Reading, USA) was inserted in the anterior chamber through the cornea at 12:00 a.m. and pushed forward in the anterior chamber until it reached the inferior limbus. At the inferior limbus, one to four sinusothalmotomie (STT) incisions were made by penetrating the anterior chamber angle with the triangle tip ( $\sim 2 \mathrm{~mm}$ deep $\mathrm{x} \sim 1.4 \mathrm{~mm}$ wide $)$ of the vitrectomy knife. Then the vitrectomy knife was withdrawn out of the eye and the clear cornea incision made watertight with a 10-0 nylon suture (Microsurgery Instruments, Bellaire, USA) and acrylic glue (Cyanoacrylate Glue, Palm Labs Adhesives, USA). Sham surgery procedures were conducted in a similar manner but without performing the incision at the inferior anterior chamber angle.

\section{Eye perfusion}

A perfusion method of the anterior chamber was used after the experimental surgical procedure. Porcine eyes were perfused with Krebs-Ringer's physiologic solution to measure the outflow facility, and, were perfused with trypan blue to measure the stained/ unstained tissue after the perfusion. Trypan blue was prepared, with Krebs-Ringer's physiologic solution, in a concentration of $0.1 \%$. The eye was connected to a narrow silastic tube by a 27 gauge needle (Terumo Medical Corporation, Tokyo, Japan). The silastic tube was connected to a three-way plastic device. The three-way plastic device was used to control the direction of the flow from a $0.5 \mathrm{ml}$ glass pipette to the narrow silastic tube, and consequently, into the porcine eye, or from a reservoir to the $0.5 \mathrm{ml}$ glass pipette. The $0.5 \mathrm{ml}$ glass pipette and the reservoir were attached to a metal support. Ninety degrees distant from the site of the clear cornea incision and at the right side, the needle was inserted through the sclera (1.0 mm distant from the limbus) and a small tunnel inside corneal stroma $(1.0 \mathrm{~mm}$ of width from the limbus to the centre of the corneal stroma) into the anterior chamber, and placed between the anterior plane of iris and the inner surface of the cornea. The heights of the column of the Krebs-Ringer's physiologic solution inside the $0.5 \mathrm{ml}$ glass pipette varied among 6.8 $\mathrm{cmH}_{2} 0(5 \mathrm{mmHg}), 13.6 \mathrm{cmH}_{2} 0(10 \mathrm{mmHg}), 20.4 \mathrm{cmH} 0$ (15 mmHg), $27.2 \mathrm{cmH}_{2} 0$ (20 mmHg), $34 \mathrm{cmH}_{2} 0$ (25 $\mathrm{mmHg}), 40.8 \mathrm{cmH}_{2} 0(30 \mathrm{mmHg}), 47.6 \mathrm{cmH}_{2} 0(35 \mathrm{mmHg})$ and $54.4 \mathrm{cmH}_{2} 0(40 \mathrm{mmHg})$. In half of the eyes of each group, the perfusion started at $6.8 \mathrm{cmH}_{2} 0(5 \mathrm{mmHg})$, and then, the height was gradually increased until $54.4 \mathrm{cmH}_{2} 0$ $(40 \mathrm{mmHg})$, and in the other half of the eyes of each 
group, the perfusion started at $54.4 \mathrm{cmH}_{2} 0(40 \mathrm{mmHg})$, and then, the height was gradually decreased until 6.8 $\mathrm{cmH}_{2} 0(5 \mathrm{mmHg})$. During the perfusion of the KrebsRinger's physiologic solution, it was not allowed to the height (volume) of the fluid of the perfusion to decrease more than $2 \mathrm{mmH}_{2} 0(5 \mu \mathrm{l})$ when the perfusion pressure was 5 or $10 \mathrm{mmHg}, 4 \mathrm{mmH}_{2} 0(10 \mu \mathrm{l})$ when the perfusion pressure was 15 or $20 \mathrm{mmHg}, 6 \mathrm{mmH}_{2} 0(15 \mu \mathrm{l})$ when the perfusion pressure was 25 or $30 \mathrm{mmHg}$, and $8 \mathrm{mmH}_{2} 0$ $(20 \mu \mathrm{l})$ when the perfusion pressure was 35 or $40 \mathrm{mmHg}$, in order not to have a significant decrease in the perfusion pressure. And, when the column of the Krebs-Ringer's physiologic solution decreased the heights (volumes) mentioned above the chronometer, that was started at the beginning of the perfusion, was stopped and the result found in minutes was used to calculate outflow facility $(\mathrm{C}=\mathrm{V} / \mathrm{mmHg} / \mathrm{min}) C=$ outflow facility, $V=$ volume of the fluid perfused, $\mathrm{mmHg}=$ perfusion pressure, min = time of the perfusion in minutes. The height of the trypan blue inside the $0.5 \mathrm{ml}$ glass pipette was fixed at $34 \mathrm{cmH}_{2} 0(25$ $\mathrm{mmHg}$ ), and $1.0 \mathrm{ml}$ of this substance was used to perfuse the porcine eyes under a constant pressure. The porcine eyes were left inside a container with the cornea up, and immersed by Krebs-Ringer's physiologic solution. In order to prevent the container of floating, it was placed on a platform that was situated inside a glass box full of water. This box had an engine to control the temperature of the water and a thermometer to check the temperature. The temperature was fixed at $39^{\circ} \mathrm{C}^{(17)}$.

After the perfusion with trypan blue, the tissue was measured with a millimeter ruler. In the middle of each quadrant, along a perpendicular line to the limbus, the distance between the limbus and the posterior border of stained/unstained tissue was measured on the conjunctiva. Then, the outer sclera was exposed by removing the conjunctiva, Tenon's capsule, and extra ocular muscles. Then, again, in the middle of each quadrant, along a perpendicular line to the limbus, the distance between the limbus and the posterior border of stained/unstained tissue was measured on the outer sclera. Finally, the globe was cut in four quadrants from the posterior pole to the limbus, and the inner sclera was made free from all intra-ocular contents (vitreous, uvea, and lens). In the middle of each quadrant, along a perpendicular line to the limbus, the distance between the limbus and the posterior border of stained/unstained tissue was measured on the inner sclera.

The eyes were also weighted by a high accurate AG 245 balance (Mettler Toledo, Greifensee, Switzerland) before and after the perfusion.

\section{Evaluation}

The mean outflow $(\mu \mathrm{l} / \mathrm{min})$ after perfusion of porcine anterior chambers with increasing perfusion pressures $\left(6,8 \mathrm{cmH}_{2} 0=5 \mathrm{mmHg}\right.$ to $54.4 \mathrm{cmH}_{2} 0=40$ $\mathrm{mmHg}$ ) was calculated with the area under the outflow facility after the surgical/sham procedure versus perfusion pressure curve, and the effect of the increasing TST incisions number ( 0 to 4 ) could be evaluated.

$\mathrm{AUC}_{\mathrm{n}-(\mathrm{n}+1)}=\frac{\mathrm{C}_{\mathrm{n}}+\mathrm{C}_{\mathrm{n}+1}}{2} \times\left(\mathrm{p}_{\mathrm{n}+1}-\mathrm{p}_{\mathrm{n}}\right)$ where:

$\mathrm{AUC}=$ area under the curve; $\mathrm{C}=$ outflow facility; $\mathrm{P}=$ perfusion pressure.

Statistical analyses of trypan blue pefusion were performed using Statistical Package for Social Sciences for Windows version 13.0 (SPSS, Inc., Cary, NC, USA). Frequency histograms and the one-sample KolmogorovSmirnov test were used to assess the distribution of numeric data for parametric characteristics. For nonparametric data, a Mann-Whitney $U$ test was used to compare means of independent samples. A $P$ value of less than 0.05 was considered statistically significant.

\section{Results}

Mean outflow facility measured during perfusion of porcine anterior chambers with increasing perfusion pressures ( 5 to $40 \mathrm{~mm} \mathrm{Hg}$ ) is shown in graphic 1 . The outflow facility increased with the increasing number of TST incisions ( 0 to 4$)$. In addition, when $20.4 \mathrm{cmH}_{2} 0$ (15 $\mathrm{mmHg}$ ) constant-pressure perfusion was reached it seemed that the outflow facility became stable (Graphic 1 ). The area under the curve calculated after perfusion of porcine anterior chambers with increasing perfusion pressures $\left(6.8 \mathrm{cmH}_{2} 0(5 \mathrm{mmHg})\right.$ to $54.4 \mathrm{cmH}_{2} 0(40$ $\mathrm{mmHg})$ ) showed that the outflow increased with the increasing TST incisions number (0 to 4) (Table 1 ).

The measurement results of the stained/unstained tissue after perfusion of porcine anterior chambers with $1 \mathrm{ml}$ of trypan blue under a constant perfusion pressure of $34 \mathrm{cmH}_{2} 0(25 \mathrm{~mm} \mathrm{Hg})$ are shown in table 2 . Thalamosinusotomy eyes demonstrated more stained tissue than sham surgery eyes with significant statistical difference $(\mathrm{P}<0.05)$ (Table 2, Figure 1).

\section{Discussion}

The STT ab interno method is a new surgical procedure that sets out to create a direct channel between the anterior chamber and the Schlemm canal. The intention of this study was to create an experimental 
Table 1

Mean outflow ( $\mu \mathrm{l} / \mathrm{min}$ ) calculated after perfusion of porcine anterior chambers with increasing perfusion pressures ( 5 to $40 \mathrm{~mm} \mathrm{Hg}$ ). Effect of increasing TST incisions number (0 to 4).

\begin{tabular}{|c|c|c|c|c|c|}
\hline & $\begin{array}{c}\text { SS } \\
\operatorname{AUC}(\mathbf{u l} / \mathrm{min})\end{array}$ & $\begin{array}{c}\text { TST } \\
1 \text { incision } \\
\text { AUC (ul/min) }\end{array}$ & $\begin{array}{c}\text { TST } \\
2 \text { incisions } \\
\text { AUC (ul/min) }\end{array}$ & $\begin{array}{c}\text { TST } \\
3 \text { incisions } \\
\text { AUC (ul/min) }\end{array}$ & $\begin{array}{c}\text { TST } \\
4 \text { incisions } \\
\text { AUC (ul/min) }\end{array}$ \\
\hline & $\mathrm{n}=8$ & $\mathrm{n}=8$ & $\mathrm{n}=8$ & $\mathrm{n}=8$ & $\mathrm{n}=8$ \\
\hline & 4.997 & 8.240 & 6.480 & 10.920 & 6.832 \\
\hline & 3.507 & 4.602 & 6.352 & 8.570 & 12.662 \\
\hline & 5.802 & 6.837 & 9.312 & 8.752 & 12.702 \\
\hline & 8.942 & 10.490 & 10.835 & 13.152 & 19.702 \\
\hline & 6.432 & 8.717 & 13.212 & 12.447 & 16.117 \\
\hline & 8.380 & 8.862 & 6.901 & 7.847 & 16.625 \\
\hline & 5.282 & 11.270 & 12.780 & 21.365 & 12.343 \\
\hline & 5.655 & 11.890 & 10.892 & 12.615 & 14.537 \\
\hline $\begin{array}{c}\text { Total } \\
(\mathrm{ul} / \mathrm{min}) \\
\text { means } \pm \text { SD }\end{array}$ & $6.125 \pm 1.784$ & $8.864 \pm 2.398$ & $9.596 \pm 2.777$ & $11.959 \pm 4.315$ & $13.940 \pm 3.812$ \\
\hline
\end{tabular}

SS: sham surgery; TST: thalamosinusotomy; AUC: area under the curve.

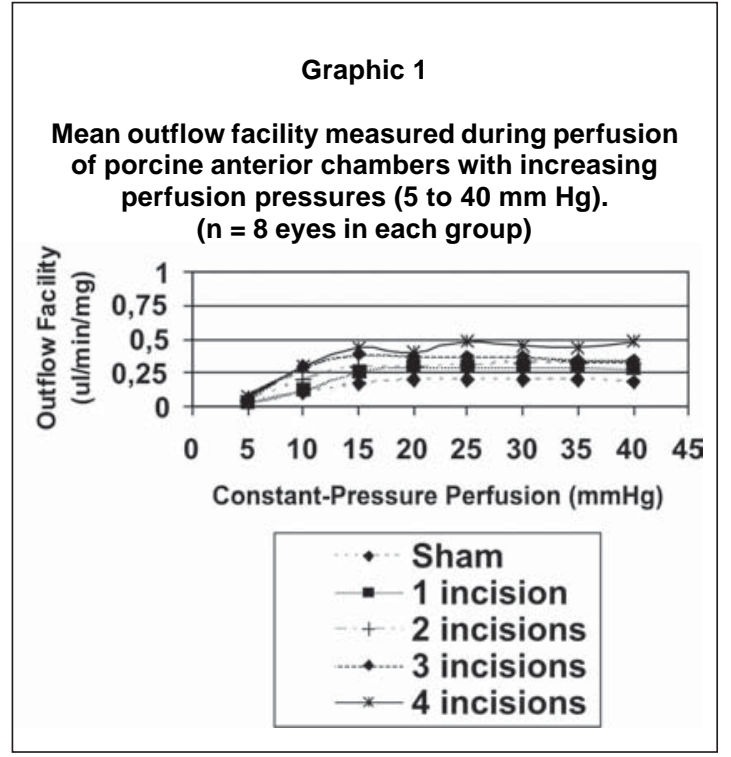

surgical procedure similar to STT ab interno in order to explore the effect of this new technique on aqueous humor drainage. The STT ab interno tip creates a deep sclerotomy with subsequent access of aqueous humor to the scleral layer ${ }^{(5)}$. In our study, it was evident by histology examination that the TST incisions reached the scleral layer of the porcine eyes through their trabecular meshwork (figure 1). Both aspects may facilitate a bypass effect of aqueous outflow. As a matter of fact about $85 \%$ of the aqueous humor drains (in physiological terms) transtrabecularly, so it is possible to suspect that exists an additional route for aqueous humor absorption in the case of elevated $\mathrm{IOP}^{(5)}$.

It was shown in the literature that such bypass effects may be present after surgical intervention which does not lead to the formation of filtering blebs. In another study $^{18}$, it was verified that eyes without filtering bleb showed very stable long-term intra-ocular pressure (IOP) regulation postoperatively.

In the light of the present knowledge, it appears that the bulk of aqueous humor outflow resistance is generated in or near the inner wall endothelium of Schlemm's canal and/or in juxtacanalicular trabecular meshwork $^{(5,7,19)}$. Some explanations are given in an attempt to elucidate this situation: collapses of Schlemm's canal $^{(20)}$, changes in inner wall pores ${ }^{(21)}$, ultrastructural modifications in the adhesions between the inner wall and the juxtacanalicular connective tissue $(\mathrm{JCT})^{(22)}$ and changes in the extracellular matrix of the JCT or the basement membrane of Schlemm's canal ${ }^{(23)}$. In addition to the bypassing of trabecular outflow resistance caused by TST ab interno, outflow resistance may be further reduced by scleral thinning at the base of the thalamus. In addition, aqueous humor could perhaps be absorbed by the ciliary body ${ }^{(1,24)}$.

To our knowledge, this is the first study where the outflow facility was assessed with an increasing thalamus number (graphic 1). And it was evident that the outflow facility increased with the increasing TST incisions 

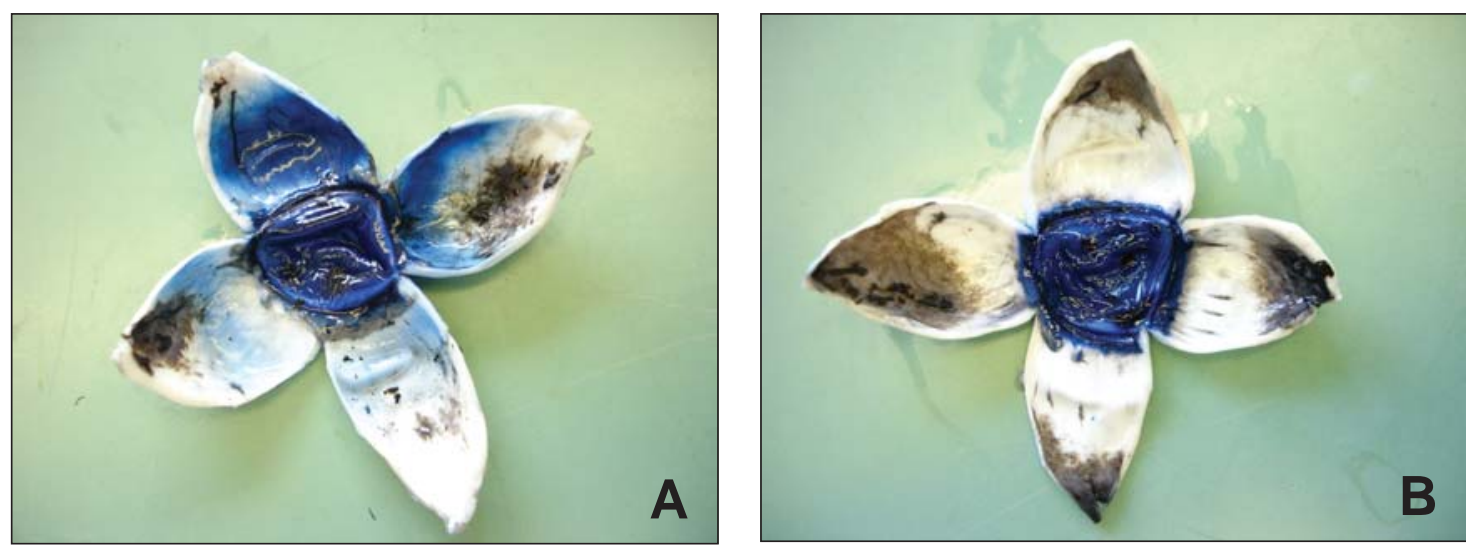

Figure 1: Stained trypan blue porcine eye. A: after thalamosinusotomy ab interno procedure; B: after sham surgery. Note more stained tissue after thalamosinusotomy.

Table 2

Stained/unstained tissue measured after perfusion of porcine anterior chambers with $1 \mathrm{ml}$ of trypan blue under a constant perfusion pressure of $34 \mathrm{cmH}_{2} \mathrm{O}(25 \mathrm{~mm} \mathrm{Hg})$.

\begin{tabular}{lccc}
\hline & $\begin{array}{c}\text { SS } \\
\mathbf{n}=\mathbf{5}\end{array}$ & $\begin{array}{c}\text { TST } \\
\mathbf{n}=\mathbf{5}\end{array}$ & $\boldsymbol{P}$ value \\
\hline CONJUNCTIVA & & & \\
Superior (mm) & $2.8 \pm 1.3$ & $5.4 \pm 1.1$ & $0.015^{\mathrm{a}}$ \\
Inferior (mm) & $2.4 \pm 0.9$ & $6.8 \pm 1.1$ & $0.007^{\mathrm{a}}$ \\
Nasal (mm) & $1.8 \pm 0.4$ & $4.2 \pm 1.1$ & $0.006^{\mathrm{a}}$ \\
Temporal (mm) & $2.0 \pm 0.7$ & $7.2 \pm 1.8$ & $0.008^{\mathrm{a}}$ \\
OUTER SCLERA & & & \\
Superior (mm) & $1.2 \pm 0.4$ & $3.6 \pm 0.5$ & $0.006^{\mathrm{a}}$ \\
Inferior (mm) & $1.6 \pm 0.5$ & $3.6 \pm 0.5$ & $0.007^{\mathrm{a}}$ \\
Nasal (mm) & $1.4 \pm 0.5$ & $2.6 \pm 0.5$ & $0.020^{\mathrm{a}}$ \\
Temporal (mm) & $1.4 \pm 0.5$ & $3.4 \pm 0.9$ & $0.013^{\mathrm{a}}$ \\
INNER SCLERA & & & \\
Superior (mm) & $1.0 \pm 0.0$ & $2.6 \pm 0.5$ & $0.005^{\mathrm{a}}$ \\
Inferior (mm) & $1.2 \pm 0.4$ & $2.8 \pm 0.4$ & $0.007^{\mathrm{a}}$ \\
Nasal (mm) & $1.0 \pm 0.0$ & $2.8 \pm 1.3$ & $0.005^{\mathrm{a}}$ \\
Temporal (mm) & $1.0 \pm 0.0$ & $2.0 \pm 0.7$ & $0.017^{\mathrm{a}}$ \\
\hline
\end{tabular}

Values are means \pm SD; SS: sham surgery; TST: thalamosinusotomy; ${ }^{\text {a: }}$ Mann Whitney test.

number ( 0 to 4$)$. And also, the area under the outflow facility curves showed that the outflow increased with the increasing TST incisions ( 0 to 4 ) (Table 1 ). Probably, it could be explained partially by the progressive reduction of aqueous humor outflow resistance after the incisions, and also by the increase of the conventional/ unconventional pathways and, perhaps, other new created pathways. And this finding could be very important clinically, owing to the fact that we will be able, in a recent future and after more studies, to select the number of incisions in relation to the amount of the outflow facility increase/decrease of IOP needed.

An interesting finding of the present study was that the outflow facility showed an increase from 6.8 $\mathrm{cmH}_{2} 0(5 \mathrm{mmHg})$ to $20.4 \mathrm{cmH}_{2} 0(15 \mathrm{mmHg})$ perfusion pressures in each TST incision, and then, it became stable from $20.4 \mathrm{cmH}_{2} 0(15 \mathrm{mmHg})$ to $54.4 \mathrm{cmH}_{2} 0(40 \mathrm{mmHg})$ (graphic 1).After $20.4 \mathrm{cmH}_{2} 0(15 \mathrm{mmHg})$, the facility of outflow was independent of the perfusion pressure in anterior segment perfusion. The reasons for this situation were not clear. However, it has already been verified that, in enucleated human eyes, from 5 to $50 \mathrm{mmHg}$, the resistance to outflow progressively increased ${ }^{(25)}$. And, it is suggested that the uveoscleral outflow is pressure independent ${ }^{(11)}$. As a result, we can speculate that the uveoscleral outflow could be important after TST, especially after $15 \mathrm{mmHg}$.

Many glaucoma surgical techniques have been developed in response to needs for achieving a lower pressure in glaucomatous patients ${ }^{(5,26-34)}$. However, not only the mechanisms by which outflow facility is increased but also where exactly the flow is going remain a subject of intense study. As a matter of fact, a question remains unclear. Where the flow actually is going after a glaucoma surgery? Some routes has been suggested after a trabeculectomy: subconjuntival absorption ${ }^{(35)}$, newly developed veins and lymphatic vessels "trabeculectomy vessels" ${ }^{\text {(36) }}$, drainage of aqueous through functioning aqueous veins, orbit tissue absorption, or uveoscleral absorption; and after a deep sclerectomy with external trabeculectomy: vaulting of residual trabecular meshwork toward the intrascleral cavity leading to widening of the cribriform interspaces, development of new aqueous veins in the intrascleral space, aqueous 


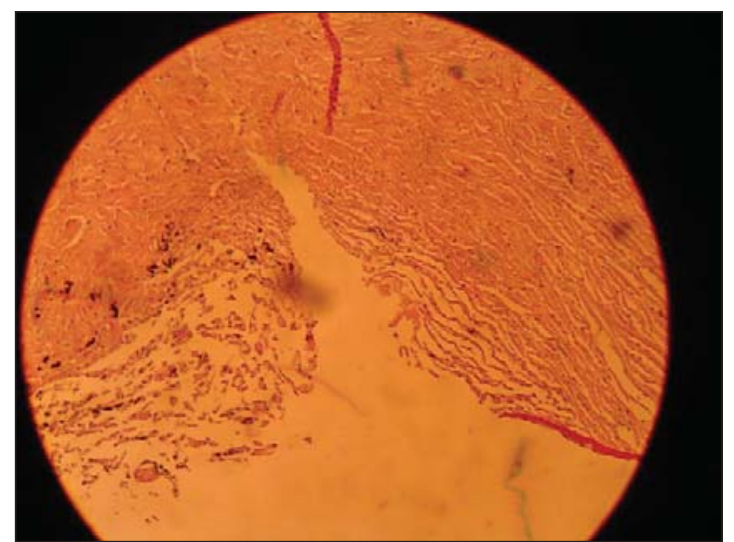

Figure 2: Histology of the thalamosinusotomy incision (the incision reached the scleral layer of the porcine eyes through their trabecular meshwork).

humor may reach the Schlemm's canal ostium from the intrascleral space and subsequently be drained in the aqueous veins, filtration to supraciliary/suprachoroidal space, and creation of a subconjunctival filtering bleb. Our study assessed the histology of the site of the incisions (Figure 2) and verified that sclera was reached by the knife during TST incision, and also it was possible to see small particles of trypan blue inside the sclera. Moreover, the measurements of the stained trypan blue tissue (Table 2, Figure 1) suggested that TST allowed the increase of the flow trough different ways: conventional pathway (conjunctiva), unconventional pathway (inner sclera), and probably the flow through the sclera (outer/ inner sclera and the particles inside sclera). So, many possible routes could be increased after TST. Certainly, further studies are necessary to clarify these cloudy points, especially with the use of tracers that would permit us to assess the flow in a dynamic way (real time).

\section{Abstract}

Purpose: To explore the effect of the thalamosinusotomy ab interno, which is an experimental surgical procedure similar to sclerothalamotomy ab interno, on aqueous humor drainage. Methods: Enucleated porcine eyes were perfused with Krebs-Ringer's physiologic solution and trypan blue, in vitro, under different constant pressures after the experimental procedure. The outflow facility and the stained/unstained tissue were measured. Results: The outflow facility and the area under the curve (outflow) increased with the increasing number of thalamosinusotomy incisions (0 to 4). Thalamosinusotomy eyes showed more stained tissue (conjunctiva, outer sclera, inner sclera) than sham surgery eyes with significant statistical difference $(P<0.05)$. Conclusions: The results suggested that outflow facility increases with the increasing number of thalamus, different pathways are stimulated after thalamosinusotomy, and the uveoscleral outflow could be an important route after the experimental surgical procedure.

Keywords: Thalamosinusotomy; Sclerothalamotomy; Aqueous humor; Drainage/methods; Swine

\section{ReFERENCES}

1. Jacobi PC, Krieglstein GK. Trabecular aspiration: a new surgical approach to improve trabecular facility in pseudoexfoliation glaucoma. Int Ophthalmol. 1994; 18(3):153-7.

2. Dietlein TS, Jacobi PC, Krieglstein GK. Ab interno infrared laser trabecular ablation: preliminary short-term results in patients with open-angle glaucoma. Graefes Arch Clin Exp Ophthalmol. 1997; 235(6):349-53.

3. Jacobi PC, Dietlein TS, Krieglstein GK. Technique of goniocurettage: a potential treatment for advanced chronic open angle glaucoma. Br J Ophthalmol. 1997; 81(4):302-7.

4. Wilmsmeyer S, Philippin H, Funk J. Excimer laser trabeculotomy: a new, minimally invasive procedure for patients with glaucoma. Graefes Arch Clin Exp Ophthalmol. 2006; 244(6):670-6.

5. Pajic B, Pallas G, Heinrich G, Böhnke M. A novel technique of ab interno glaucoma surgery: follow-up results after 24 months. Graefes Arch Clin Exp Ophthalmol. 2006; 244(1): 22-7.

6. Grant WM. Further studies on facility of flow through the trabecular meshwork. AMA Arch Ophthalmol. 1958; 60(4 Pt 1):523-33.

7. Grant WM. Experimental aqueous perfusion in enucleated human eyes. Arch Ophthalmol. 1963; 69:783-801.

8. Peterson WS, Jocson VL, Sears ML. Resistance to aqueous outflow in the rhesus monkey eye. Am J Ophthalmol. 1971; 72(2):445-51.

9. Bill A, Phillips CI. Uveoscleral drainage of aqueous humour in human eyes. Exp Eye Res. 1971; 12(3):275-81.

10. Bill A. Uveoscleral drainage of aqueous humor: physiology and pharmacology.Prog Clin Biol Res. 1989; 312:417-27.

11. Bill A. Conventional and uveo-scleral drainage of aqueous humour in the cynomolgus monkey (Macaca irus) at normal and high intraocular pressures. Exp Eye Res. 1966; 5(1):45-54.

12. Bill A. Blood circulation and fluid dynamics in the eye. Physiol Rev. 1975; 55(3):383-417.

13. Pederson JE, Gaasterland DE, MacLellan HM. Uveoscleral aqueous outflow in the rhesus monkey: importance of uveal reabsorption. Invest Ophthalmol Vis Sci. 1977; 16(11):1008-17.

14. Sherman SH, Green K, Laties AM. The fate of anterior chamber fluorescein in the monkey eye. 1. The anterior chamber outflow pathways. Exp Eye Res. 1978; 27(2):159-73.

15. Suguro K, Toris CB, Pederson JE. Uveoscleral outflow following cyclodialysis in the monkey eye using a fluorescent tracer. Invest Ophthalmol Vis Sci. 1985; 26(6):810-3.

16. Toris CB, Yablonski ME, Wang YL, Camras CB. Aqueous humor dynamics in the aging human eye. Am J Ophthalmol. 1999; 127(4): 407-12.

17. Camber O, Rehbinder C, Nikkila T, Edman P. Morphology of the pig cornea in normal conditions and after incubation in a perfusion apparatus. Acta Vet Scand. 1987; 28(2):127-34. 
18. Pallas G, Pajic B. Die Sklerothalamektomie (STE): Stabile postoperative Augendruckregulierung beim Offenwinkel- und Kapselhäutchenglaukom. Klin Monatsbl Augenheilkd. 2000; 216(5):256-60

19. Weekers R, Watillon M, De Rudder M. Experimental and clinical investigations into the resistance to outflow of aqueous humour in normal subjects. Br J Ophthalmol. 1956; 40(4):225-33.

20. Hashimoto JM, Epstein DL. Influence of intraocular pressure on aqueous outflow facility in enucleated eyes of different mammals. Invest Ophthalmol Vis Sci. 1980; 19(12):1483-9.

21. Johnson M, Shapiro A, Ethier CR, Kamm RD. Modulation of outflow resistance by the pores of the inner wall endothelium. Invest Ophthalmol Vis Sci. 1992; 33(5):1670-5.

22. Overby D, Gong H, Qiu G, Freddo TF, Johnson M. The mechanism of increasing outflow facility during washout in the bovine eye. Invest Ophthalmol Vis Sci. 2002; 43(11):3455-64.

23. Lütjen-Drecoll E, Gabelt BT, Tian B, Kaufman PL. Outflow of aqueous humor. J Glaucoma. 2001; 10(5 Suppl 1):S42-4. Review.

24. Schwenn O, Dick B, Pfeiffer N. Trabekulotomie, tiefe Sklerektomie und Viskokanalostomie. Nicht fistulierende mikrochirurgische Glaukomoperationen ab externo. Ophthalmologe. 1998; 95(12):835-43.

25. Ellingsen BA, Grant WM. The relationship of pressure and aqueous outflow in enucleated human eyes. Invest Ophthalmol. 1971; 10(6):430-7.

26. Barkan O. A new operation for chronic glaucoma. Am J Ophthalmol. 1936; 19:951-66.

27. Smith R. A new technique for opening the canal of Schlemm. Preliminary report. Br J Ophthalmol. 1960; 44:370-3.

28. Allen L, Burian HM. Trabeculotomy ab externo. A new glaucoma operation: technique and results of experimenta surgery. Am J Ophthalmol. 1962; 53:19-26.
29. Krasnov MM. [Sinusotomy in glaucoma]. Vestn Oftalmol 1964; 77:37-41. Russian.

30. Cairns JE. Trabeculectomy. Preliminary report of a new method. Am J Ophthalmol. 1968; 66(4):673-9.

31. Krasnov MM. Microsurgery of glaucoma. Indications and choice of techniques. Am J Ophthalmol. 1969; 67(6):857-64.

32. Ackerman J, Kanarek IE, Shamah M et al: A new approach to aphakic glaucoma: A subscleral filtering cyclidialysis. Glaucoma. 1979; 3:176-83

33. Fedorov SN, Ioffe DI, Ronkina TI. [Glaucoma surgery-deep sclerectomy]. Vestn Oftalmol. 1982; (4):6-10. Russian.

34. Stegmann R, Pienaar A, Miller D. Viscocanalostomy for openangle glaucoma in black African patients. J Cataract Refract Surg. 1999; 25(3):316-22. Comment in: J Cataract Refract Surg. 1999; 25(3):297. J Cataract Refract Surg. 1999; 25(3):298-300. J Cataract Refract Surg. 1999; 25(10):1309.

35. Ridgway AE, Rubinstein K, Smith VH. Trabeculectomy. A study of 86 cases. Br J Ophthalmol. 1972; 56(7):511-6.

36. van der Zypen E, Fankhauser F, Kwasniewska S. The mechanism of aqueous outflow following trabeculectomy. A light and electron microscopic study. Int Ophthalmol. 1989; 13(3):219-28

\section{ENDEREÇO PARA CORRESPONDÊNCIA \\ Rafael Vidal Mérula \\ Rua Espírito Santo, 1315/402. Bairro Centro. \\ Juiz de Fora - MG. \\ CEP 36015-430}

Fax: 3232168389

e-mail: rafaelmerula@hotmail.com 